\title{
耳鼻咽喉科の保険診療一現状の問題点と将来一 一司会のことば一
}

\author{
大阪医科大学学長 \\ 竹 中 洋
}

耳鼻咽喉科の保険診療は, 厚労省の定める 2 年に一度の診療報酬改定と外保連等の技術評価ならびに日本医師会の疑 義解釈委員会等の上にたつ総合事業と考えることができる，診療報酬改定には中医協審議が先行し，中医協審議案件に は技術度評価や高度で先進的な技術評価など主に学会が指導性を発揮できるものから, DPC や診断群分類等のように， 診療実績から基準化・標準化が行われるが学会が意思表示を示すことができるもの，さらには医療提供体制全体として 学会にほとんど選択性がない診察料のように決定されて行くものがある.

日耳鼻保険医療委員会が, 保険診療政策と共存していくシステムとして構築してきたものを著者が知る範囲で年代順 に列挙する.

(1) 平成10年からの包括化支払制度の試行

(2) 平成16年からの都道府県定点での診療実態調查

(3) 同年度からの外保連技術料評価への積極的参加

(4) ブロック会議形式から全国協議会への委員会活動の変更

(5) WS における委員会活動報告

(1)は DPC 制度として定着し, 耳鼻咽喉科・頭頸部外科の入院治療は, 基準化され標準化されてきた，併せて(3)外 保連での手術の技術度評価は大きく耳鼻咽喉科特性を反映したものに移行してきた．また，2(2都道府県保険医療委員 会の協力を得て精緻化され，(4)，(5)と共に耳鼻咽喉科全体としての診療評価意識の共有に貢献してきたと考えている.

これら多くの保険診療にかかわる変更は, 故・志多 享顧問と歴代理事長の指示と理解に依るところが極めて大きい が，一方，当時から考慮されてきた「耳鼻咽喉科実地臨床情報」の透明化や周知を促進するためには，10年間の蓄積を 経た現在客観視が必要であろう。折しも中医協で都道府県単位の医療技術評価や薬物の使用について差があることなど が指摘されている．電子カルテの導入が略完成した平成 28 年度改定では，これらの課題が表面化すると考えられる.

本専門医講習会では，診療実態調査から見えてくる実地医家診療を課題として上げ，処置，検査ならびに管理料を含 む診察について現状と問題点・課題を取りまとめて頂く，手術については歴史的術式から離れ，現在の手術の在り方を 追求した鼻副鼻垫炎術式の導入をモデルに 21 世紀の術式についての方向性を探る一歩としたい．少子超高齢化多死時代 を迎え，高度専門医としての耳鼻咽喉科医の役割は見えていない，また，学会も示せていない。その中で保険診療の十 年の歩みを振り返り, 今後の四半世紀の方向性が何とか共有できれば幸いである. 